\title{
Septibranchia (Mollusca: Bivalvia) from the North and Northeast Coasts of Brazil
}

\author{
Cristiane Xerez Barroso ${ }^{1 *}$, Sula Salani², Soraya Guimarães Rabay ${ }^{1}$ and Helena Matthews-Cascon ${ }^{1,3}$
}

\begin{abstract}
Background: Septibranchia comprises groups of bivalves that have developed a series of anatomical and conchological modifications toward a carnivorous and/or saprophagic lifestyle. The present study aims to identify the species of the families Poromyidae, Cuspidariidae and Verticordiidae found off the northern and north-eastern coasts of Brazil, reducing the gaps in the geographic distribution and adding new morphological data of the analysed shells.

Results: Six genera and eight species were found in the 54 examined lots: Cardiomya cleryana, Cardiomya ornatissima, Cardiomya perrostrata, Cuspidaria sp., Plectodon braziliensis, Myonera aff. paucistriata, Poromya cf. granulata and Trigonulina ornata. The present study adds new conchological and morphometric characteristics to descriptions of species, redulces the gap in the distribution of Plectodon braziliensis in the Southwestern Atlantic, and extends the northern distribution limit of $P$. braziliensis and $C$. cleryana with new records for off the northnorth-east coast of Brazil.

Conclusions: By adding new morphological and morphometric data of the shells, the present study may help in the taxonomy of these septibranch species. New collections in the region will probably lead to the discovery of new records of Septibranchia.
\end{abstract}

Keywords: Cardiomya, Plectodon, Cuspidaria, Myonera, Trigonulina, Poromya

\section{Background}

Anomalodesmata Dall, 1889, which diversified early in the Palaeozoic, is a monophyletic clade, globally distributed and represented today by a diverse assemblage of highly specialised marine shallow and deep waters bivalves (Harper et al. 2006; Bieler et al. 2014). Several families of anomalodesmatans have become carnivorous, showing a series of remarkable anatomical and conchological modifications for the capture of small arthropods and polychaetes (Harper et al. 2006; Morton 1981). This main group of carnivorous taxa has been grouped together as the 'septibranchs' (Harper et al. 2006). Some analyses of molecular and/or morphological data support a deep division of Anomalodesmata into three clades: Septibranchia and two lineages corresponding to the 'lyonsiid' and largely to the 'thraciid' lineages (Harper et al. 2006; Bieler

\footnotetext{
* Correspondence: cristianexb@gmail.com

'Laboratório de Invertebrados Marinhos do Ceará, Departamento de Biologia, Centro de Ciências, Universidade Federal do Ceará, Rua Campus do Pici, s/n, Bloco 909, Pici, CEP: 60440-900 Fortaleza, CE, Brazil

Full list of author information is available at the end of the article
}

et al. 2014). However, the origin of the carnivorous septibranch mode of life remains unresolved, due to conflicting results from different analyses (Bieler et al. 2014). This study will discuss three families within Anomalodesmata: Poromyidae Dall, 1886, Cuspidariidae Dall, 1886, and Verticordiidae Stoliczka, 1870.

Poromyidae is characterized by a small, fragile, inflated, and usually equivalve shell, with a rounded anterior end and a truncate posterior end; it is sculptured with radial striae or granulates (Olsson 1961; Abbott 1974; Coan et al. 2000). Species of this family have exhalant siphon short and inhalant siphon eversible into large raptorial hoods; their gills are absent and they are simultaneously hermaphroditic (Abbott 1974; Coan et al. 2000). Poromyidae, known from Cretaceous, is widely distributed in deep water, where they are shallowly infaunal in fine sediments (Olsson 1961; Abbott 1974).

Cuspidariidae species are mostly inhabitants of deep water, occurring between 4 and 6,800 $\mathrm{m}$ depth (Abbott 1974; Coan et al. 2000; Coan and Valentich-Scott 2012). Cuspidariids have separate sexes and are carnivores or 
detritus consumers. Their shell is generally small, thin, inflated, and inequilateral, with a rounded and convex anterior end and rostrate or pointed posterior end (drawn out into the tubular rostrum in many) (Olsson 1961; Abbott 1974; Coan et al. 2000).

Verticordiidae, known from the early Cretaceous, contains highly modified genera, mostly deep-water infauna capturing and feeding on small invertebrates (Coan et al. 2000). The shell is generally small, cardiform, equivalve, inequilateral, and inflated; radial sculpture is usually present, often of riblets or lirae; the surface is often granular or spinose (Olsson 1961; Coan et al. 2000).

According to Rios (2009) and Oliveira (2012), 37 species are recorded in these families in Brazil: two genus and three species in Poromyidae, seven genus and 26 species in Cuspidariidae, and five genus and eight species in Verticordiidae. Studies on the north-north-east coast of Brazil are still scarce, with a majority of studies focusing on the south-eastern region (Oliveira 2012; Oliveira and Absalão 2007, 2009, 2010a, 2010b; Simone and Cunha 2008; Absalão and Oliveira 2011). According to these studies, nine species are registered to the northnorth-east coast of Brazil (Poromya granulata (Nyst \& Westendorp, 1839), Cuspidaria circinata (Jeffreys, 1876), Cuspidaria monosteira Dall, 1890, Cuspidaria rostrata (Spengler, 1793), Protocuspidaria verityi Allen \& Morgan, 1981, Plectodon braziliensis (E. A. Smith, 1915), Spinosipella agnes Simone \& Cunha, 2008, Verticordia woodii E. A. Smith, 1885, and Trigonulina ornata d'Orbigny, 1842). Rios (Rios 2009) recorded Cardiomya ornatissima (d'Orbigny, 1853) and Cardiomya perrostrata (Dall, 1881) in Brazilian waters, but did not specify the localities.

The present study aims to identify the species of the families Poromyidae, Cuspidariidae and Verticordiidae found in the northern and north-eastern coasts of Brazil, reducing the gaps in the geographic distribution and adding new morphological data for the analysed shells.

\section{Results}

Six genera and eight species were found in the 54 examined lots, whose identification was based on Oliveira and Absalão (2009, 2009, 2010a, b), Bieler et al. (2010), Pimpão et al. (2010), and Absalão and Oliveira (2011) and is presented below. Cuspidariidae was the most represented family with four genera and six species: Cardiomya cleryana (d'Orbigny, 1842), Cardiomya ornatissima (d'Orbigny, 1853), Cardiomya perrostrata (Dall, 1881), Cuspidaria sp., Plectodon braziliensis (E. A. Smith, 1915), and Myonera aff. paucistriata Dall, 1886. Poromyidae and Verticordiidae were represented by Poromya cf. granulata (Nyst \& Westendorp, 1839) and Trigonulina ornata d'Orbigny, 1842, respectively.

\section{Identification key}

The dichotomous identification key proposal to identify the eight studied species is below.

1a. With rostrum...................................................................... 2

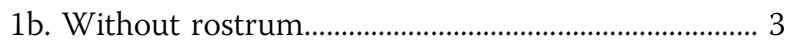

2a. Rostrum broader than long ................... Myonera aff. paucistriata

2b. Rostrum longer than wide 4

3a. Circular shell with radial ribs and deep lunule Trigonulina ornata

3b. Surface of shell granulose. Poromya cf. granulata

4a. With radial ribs 5

4b. Without radial ribs........................................................ 6

5a. Strong radial ribs (6 to 16 primary ribs) with interspaces, ribs well marked on the inner surface of the valve Cardiomya ornatissima

5b. Variable number of radial ribs (14-36) with interspaces 7

6a. External surface with granules...................... Plectodon braziliensis

6b. External surface without granules. Cuspidaria sp.

7a. 14 to 32 radial ribs with different sizes. Cardiomya perrostrata

7b. 15 to 36 radial ribs of equal size, shell with pronounced anterior projection next to umbones. Cardiomya cleryana

\section{Descriptions of species}

SYSTEMATICS

ANOMALODESMATA Dall, 1889

Superfamily POROMYOIDEA Dall, 1886

Family POROMYIDAE Dall, 1886

Genus Poromya Forbes, 1844

Poromya cf. granulata (Nyst \& Westendorp, 1839)

(Figs. 1 and 2)

Synonymy: Poromya rotundata Jeffreys, 1876 (Rios 2009); see the checklist made by Janssen and Krylova (2014) for synonymys.

Material examined: CMPHRM 2030A, 2 right valves, Oc.V. Almirante Saldanha, Brazil, Off Pará, $0^{\circ}$ $29^{\prime} \mathrm{N} 47^{\circ} 24^{\prime} \mathrm{W}$.

Description: Valve small $(5.44-7.63 \times 5.59-8.44 \mathrm{~mm})$, ovate, both ends rounded, posterior region aslope. Color white to cream, inner surface subnacreous. Umbones prominent subcentral, turned to the anterior region. Outer surface with minute granules spread over the entire surface. Internal margins smooth. Right valve with a strong cardinal tooth in front of chondrophore.

Geographic distribution: Atlantic Ocean: Artic Seas to Caribbean and Brazil (Amapá and São Paulo), Mediterranean Sea (Rios 2009; Janssen and Krylova 2014). 


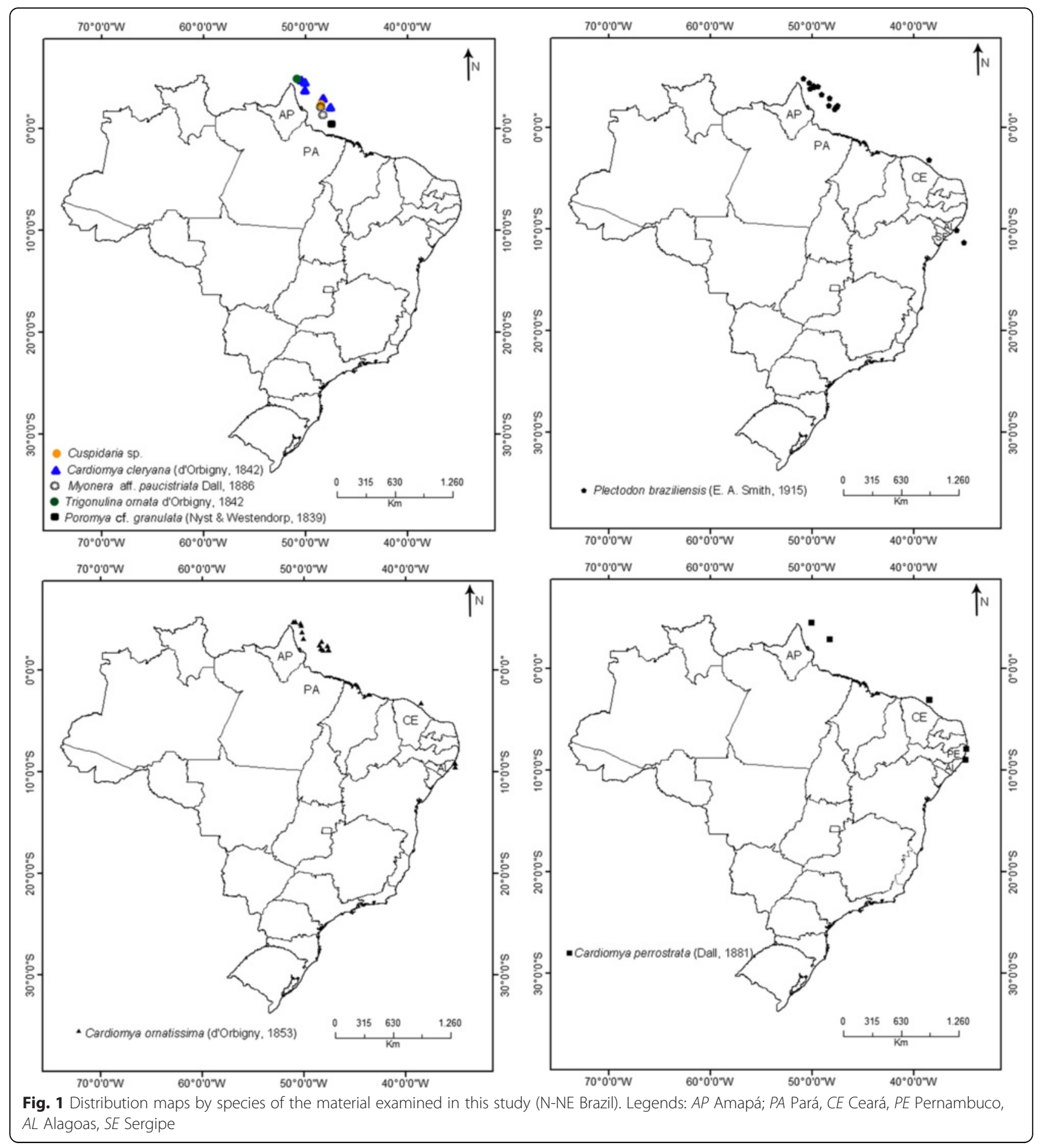

In the present study, this species was recorded for off the coast of Pará (north Brazil).

Bathymetric distribution: $21 \mathrm{~m}$ (present study); 85 to $150 \mathrm{~m}$ (Rios 2009); 30 to 2,719 m (Janssen and Krylova 2014).

Remarks: This material was allocated in the genus Poromya because it has an external surface sculptured with fine granules and right valve with a strong cardinal tooth in front of a chondrophore. Other four living genera are recognized in Poromyidae: Cetomya Dall, 1889 (weak cardinal tooth in right valve), Dermatomya Dall, 1889 (smooth outer surface), Lissomya Krylova, 1997 (smooth outer surface), and Dilemma Leal, 2008 (shell strongly compressed in the anteroposterior direction) (Coan et al. 2000; Krylova 1997; Leal 1764). According to Rios (2009) and Oliveira (2012), two species are recorded 


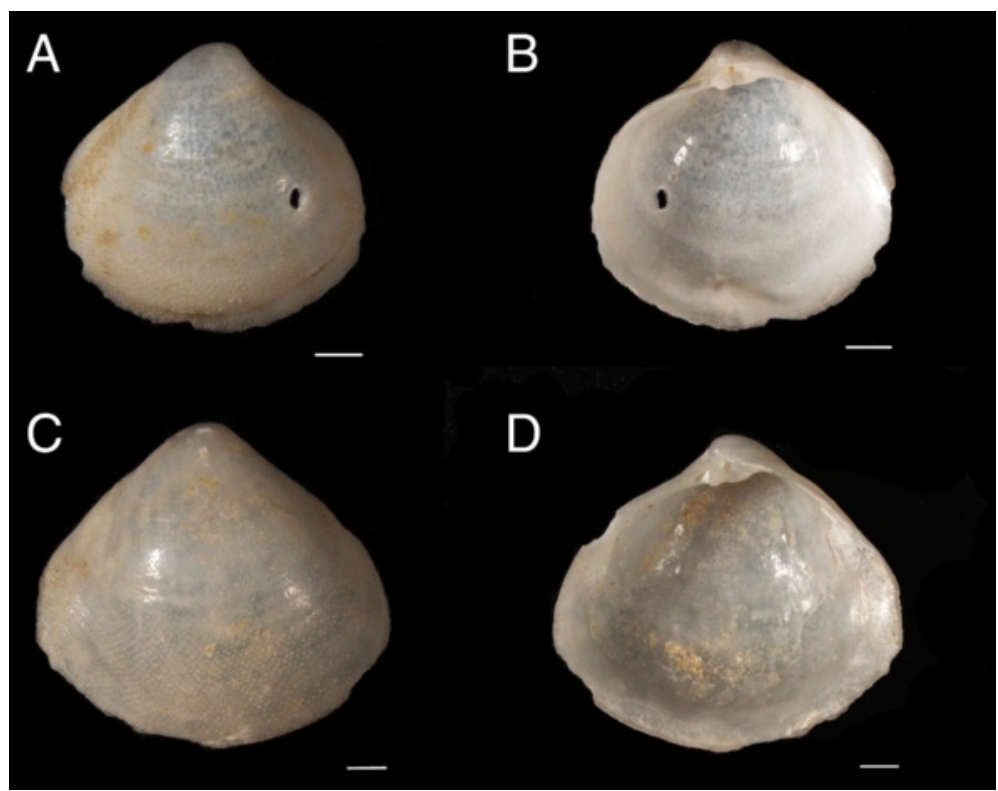

Fig. 2 Poromya cf. granulata (Nyst \& Westendorp, 1839) (CMPHRM 2030A). Legends: (a) and (c) External views of the right valve; (b) and (d) Internal views of the right valve. Scale bars: A-D, $1 \mathrm{~mm}$

in genus Poromya in Brazil: Poromya granulata and Poromya cymata Dall 1890 and they differ because $P$. granulata has both ends rounded and a greater number of minute granules in the external surface, whereas $P$. cymata has a posterior end with a narrow, radial keel (Rios 2009). The examined material in this study has both ends rounded and an external surface with numerous granules, just like $P$. granulata sensu Rios (2009), but is distinguished from the latter mainly by the non-elongated posterior end. This difference may be due to the fact that our material is of young specimens. Thus, we prefer to identify it as Poromya cf. granulata.

According to Bieler et al. (2010), two families are recorded in superfamily Poromyoidea: Poromyidae and Cetoconchidae Ridewood, 1903, and one genera is recognized in Cetoconchidae: Cetoconcha Dall, 1886. Cetoconcha differs from Poromya mainly by "the dentition obsolete except the cardinal tooth of the right valve, which itself is sometimes absent in the adult, though observable in the young shells" (p. 280) (Dall 1886). Our specimens could be juveniles of Cetoconcha. However, our material differs from the descriptions of species of Cetoconcha (e.g., Cetoconcha bulla (Dall, 1881) and Cetoconcha braziliensis Allen \& Morgan, 1981), especially regarding ornamentation present in the outer surface. Cetoconcha bulla has a "shell smooth, except that a faint impression of radiating lines is left by the epidermis" (p. 107) (Dall 1881), while C. braziliensis has a "shell surface with faint, concentric growth lines, about 13 posterior radial lines of granules, more distinct ventrally" (p. 521) (Allen and Morgan 1981). Thus, we decided to keep our material in genus Poromya. Unfortunately, it was not possible to identify more accurately the specimens due to the existence of only two young right valves.

Superfamily CUSPIDARIOIDEA Dall, 1886

Family CUSPIDARIIDAE Dall, 1886

Genus Cuspidaria Nardo, 1840

Cuspidaria sp.

(Figs. 1 and 3)

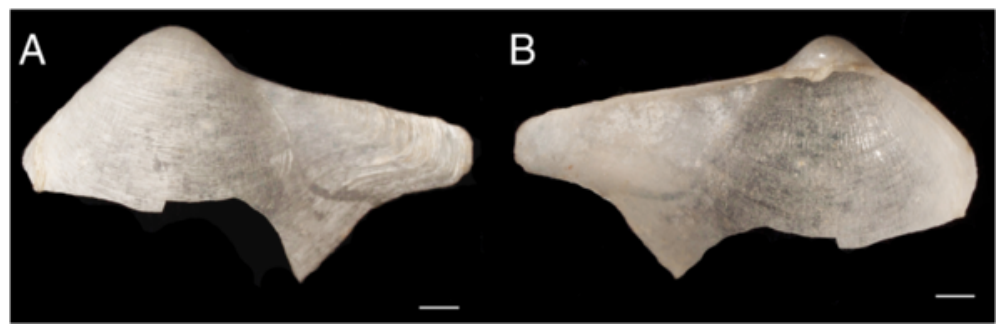

Fig. 3 Cuspidaria sp. (CMPHRM 3665A). Legends: (a) External view of the left valve; (b) Internal view of the left valve. Scale bars: a-b, 1 mm 
Material examined: CMPHRM 3665A, 1 left valve, Oc.V. Almirante Saldanha, Brazil, Off Pará, $2^{\circ} 29^{\prime} 00^{\prime \prime} \mathrm{N}$ 48³0'00"W, 09 December 1970.

Description: Shell globose (11.53 $\mathrm{mm}$ in length), inequilateral, moderately convex, rostrate posteriorly (2.50 mm in length). Color white, not shiny. Sculptured with fine radial lines. Left valve without teeth, with a small fossete.

Geographic distribution: Atlantic Ocean: off the coast of Pará (north Brazil)

Bathymetric distribution: $77 \mathrm{~m}$ deep

Remarks: This material was allocated in the genus Cuspidaria Nardo, 1840 because it has a smooth external surface with fine growth lines, without granules. Absalão and Oliveira (2011) carried out a revision of the species of Cuspidaria present on the continental slope $(700-2,000 \mathrm{~m})$ of the Campos Basin $\left(22^{\circ} \mathrm{S}\right)$ off southeastern Brazil, describing two new species. According to Oliveira (2012), 11 species are recorded in genus Cuspidaria in Brazil: Cuspidaria rostrata (Spengler, 1793), C. circinata (Jeffreys, 1876), C. papyria (Jeffreys, 1876), C. platensis (Smith, 1885), C. wollastonii (Smith, 1885), Cuspidaria? monosteira Dall, 1890, C. parva Verrill \& Bush, 1898, Cuspidaria cf. barnardi Knudsen, 1970, C. krylovae Allen, 2011, C. tamandua Absalão \& Oliveira, 2011, and C. wapixana Absalão \& Oliveira, 2011. The material examined in this study does not appear to belong to any known species of Cuspidaria. Unfortunately, it was not possible to identify the specimen at a specific level due to its poor preservation and the existence of a single left valve.

Genus Plectodon Carpenter, 1865

Plectodon braziliensis (E. A. Smith, 1915)

(Figs. 1 and 4, Table 1)

Synonymy: See the revision made by Pimpão et al. (2010) for synonyms.
Material examined: CMPHRM 3656A, 1 left valve, Oc.V. Almirante Saldanha, Brazil, Off Amapá, 3¹0'30" N 4900'18"W, 13 September 1970; CMPHRM 3658A, 2 right valves, Oc.V. Almirante Saldanha, Brazil, Off Amapá, 344'30"N 5007'30"W, 08 May 1971; CMPHRM 3672A, 1 right valve, Oc.V. Almirante Saldanha, Brazil, Off Amapá, 354'00"N 4947'30"W, 09 May 1971; CMPHRM 3653A, 1 right valve, Oc.V. Almirante Saldanha, Brazil, Off Amapá, 355'30"N 49²1'30"W, 19 May 1971; CMPHRM 3655A, 1 valve, Oc.V. Almirante Saldanha, Brazil, Off Amapá, 401'30"N 4953'00"W, 09 May 1971; CMPHRM 3652A, 1 right valve, Oc.V. Almirante Saldanha, Brazil, Off Amapá, 420'00"N 50¹8'00"W, 07 May 1971; CMPHRM 2020A, 1 right valve and 1 left valve, Oc.V. Almirante Saldanha, Brazil, Off Amapá, 446 '00 "N 5046'30"W, 06 May 1971; CMPHRM 3667A, 1 right valve, Oc.V. Almirante Saldanha, Brazil, Off Pará, $1^{\circ} 47^{\prime} 00^{\prime \prime} \mathrm{N} 47^{\circ} 49^{\prime} 00^{\prime \prime} \mathrm{W}, 20$ April 1971; CMPHRM 3673A, 1 right valve, Oc.V. Almirante Saldanha, Brazil, Off Pará, $1^{\circ} 55^{\prime} 30^{\prime \prime} \mathrm{N}$ 47\% $41^{\prime} 00^{\prime \prime} \mathrm{W}, 20$ April 1971; CMPHRM 3654A, 3 right valves and 2 left valves, Oc.V. Almirante Saldanha, Brazil, Off Pará, 201 '00" N 47³2'30"W, 20 April 1971; CMPHRM 3696A, 1 right valve, Oc.V. Almirante Saldanha, Brazil, Off Pará, 206'30" N 48 24'00"W, 23 April 1971; CMPHRM 3683A, 1 right valve, Oc.V. Almirante Saldanha, Brazil, Off Pará, 209'00" N 47²5'30"W, 19 May 1971; CMPHRM 3684A, 1 right valve and 4 left valves, Oc.V. Almirante Saldanha, Brazil, Off Pará, 253'00"N 48¹7'00"W, 14 September 1970; CMPHRM 715A, 2 right valves and 5 left valves, Canopus, Brazil, Off Ceará, $3^{\circ} 13^{\prime} \mathrm{S} 38^{\circ} 31^{\prime} \mathrm{W}$, June 1965 to February 1966; CMPHRM 3697A, 1 right valve, Akaroa, Brazil, Off Alagoas, $10^{\circ} 5^{\prime} 7^{\prime \prime} \mathrm{S} \quad 35^{\circ} 47^{\prime} 2^{\prime \prime} \mathrm{W}, 04$ November 1965; CMPHRM 3682A, 1 left valve, Canopus, Brazil, Off Sergipe, $11^{\circ} 19^{\prime} 0^{\prime \prime} \mathrm{S} 35^{\circ} 05^{\prime} 0^{\prime \prime} \mathrm{W}, 20$ March 1966;

Description: Shell elongate $(19.5 \times 12.4 \mathrm{~mm})$, moderately globose, rostrate posteriorly. Dorsal margins obliquely

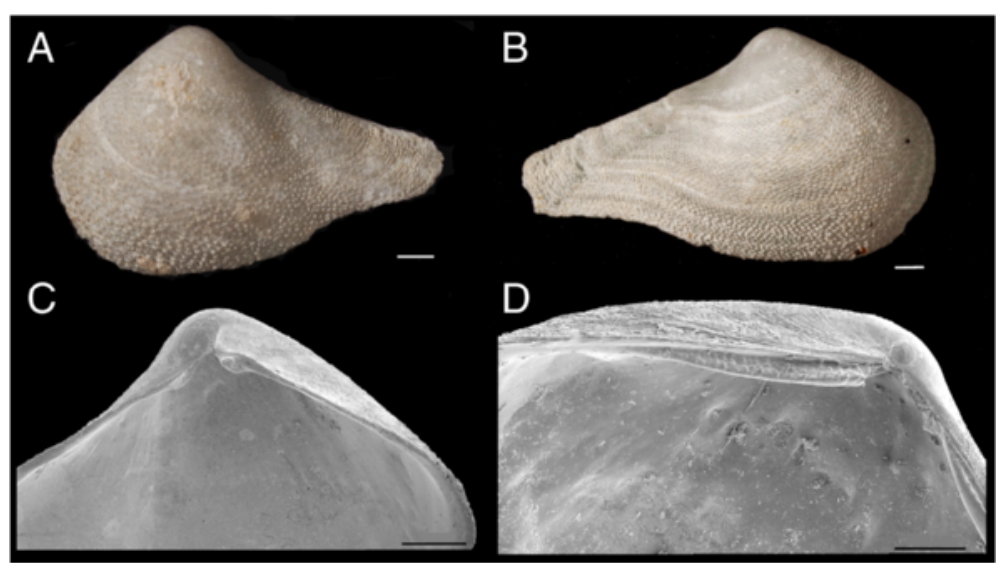

Fig. 4 Plectodon braziliensis (E. A. Smith, 1915) (CMPHRM 3684A). Legends: (a) External view of the left valve; (b) External view of the right valve; (c) Hinge of the left valve; (d) Hinge of the right valve. Scale bars: a-c, $1 \mathrm{~mm}$; d, $500 \mu \mathrm{m}$ 
Table 1 Some morphometric data of Plectodon braziliensis (E.A. Smith, 1915). Comparative data on the length and height of the valves and size of rostrum of the examined material. Dimensions in $\mathrm{mm}$. The number in italics means the average value of the measurement

\begin{tabular}{|c|c|c|c|c|}
\hline Examined material & Length (mm) & Height $(\mathrm{mm})$ & Rostrum (mm) & Val. $\left(n^{\circ}\right)$ \\
\hline \multirow{2}{*}{ CMPHRM 715A } & $13.48-^{*}$ & $6.3-7.5$ & * & $R(2)$ \\
\hline & $13-13.9-14.5$ & $6.9-7.2-8.4$ & 4.0 & $L(5)$ \\
\hline \multirow[t]{2}{*}{ CMPHRM 2020A } & 15.5 & 8.34 & $4.0^{*}$ & $R(1)$ \\
\hline & $*$ & 7.85 & * & $L(1)$ \\
\hline CMPHRM 3652A & 14.36 & 6.49 & $0.7^{*}$ & $R(1)$ \\
\hline CMPHRM 3653A & 12.23 & 7.04 & 2.3 & $R(1)$ \\
\hline \multirow[t]{2}{*}{ CMPHRM 3654A } & $14.2-16.4-19.5$ & $8.7-10.2-12.4$ & $2.3-2.7-3.0$ & $R(3)$ \\
\hline & $7.7-16.0$ & $4.0-9.5$ & $1.6-3.5^{*}$ & $L(2)$ \\
\hline CMPHRM 3655A & * & * & * & $*(1)$ \\
\hline CMPHRM 3656A & 16.3 & 8.7 & $5.5^{*}$ & $L(1)$ \\
\hline CMPHRM 3658A & $9.6-17.9$ & $6.6-11.5$ & $1.2^{*}-4.9^{*}$ & $R(2)$ \\
\hline CMPHRM 3667A & 8.2 & 4.4 & * & $R(1)$ \\
\hline CMPHRM 3672A & 7.8 & 4.1 & * & $R(1)$ \\
\hline CMPHRM 3673A & 15.3 & 9.6 & 4.1 & $R(1)$ \\
\hline CMPHRM 3682A & 9.7 & 5.6 & * & $\mathrm{L}(1)$ \\
\hline CMPHRM 3683A & 7.9 & 4.7 & * & $R(1)$ \\
\hline \multirow[t]{2}{*}{ CMPHRM 3684A } & 10.3 & 6.8 & 3.2 & $R(1)$ \\
\hline & 8.9-10.9-14.3 & $4.3-6.6-8.6$ & $2.0^{*}-3.2-5.0$ & $L(4)$ \\
\hline CMPHRM 3696A & 10.8 & 6.1 & * & $R(1)$ \\
\hline CMPHRM 3697A & 7.9 & 5.3 & $2.19^{*}$ & $R(1)$ \\
\hline
\end{tabular}

Legend: CMPHRM-A malacological collection "Prof. Henry Ramos Matthews" - series A, Val. Valve, $\left(n^{\circ}\right)$ number of examined valves, $R$ right, $L$ left; ${ }^{*}$ damaged shell

angled on either side of beaks, anterior straight at first, then curving into the rounded end. Rostrum rounded posteriorly. Color white, inner surface shiny (polished). Inequilateral, posterior end longer, umbones slightly opisthogyrate. Outer surface with fine growth lines and dense minute granules. Hinge in the right valve with elongate (lamellar) lateral teeth (anterior and posterior). Hinge in the left valve without teeth, with small fossete.

Geographic distribution: Atlantic Ocean: Brazil (Ceará, Rio de Janeiro, Santa Catarina and Rio Grande do Sul) (Rios 2009; Pimpão et al. 2010). In the present study, this species was recorded for off the north-north-east coast of Brazil (Amapá, Pará, Ceará, Alagoas, and Bahia).

Bathymetric distribution: 72 to 100 m (Rios 2009); 27 to $290 \mathrm{~m}$ (present study).

Habitat: Sandy with biodetritus, muddy sand (Rios 2009; Pimpão et al. 2010).

Remarks: Plectodon braziliensis was formerly placed in the genus Cuspidaria, but Pimpão et al. (2010) reallocated it in genus Plectodon because it has minute granules upon the external surface. According to these authors, Plectodon braziliensis is the only species of this genus recorded from Brazil. Plectodon braziliensis is distinguished from $P$. scaber (from the Pacific Ocean) mainly by a rose-tinged umbo (Pimpão et al. 2010). This study reduces the gap in the distribution of $P$. braziliensis in the South-western Atlantic and extends the northern distribution limit with new records for off the northnorth-east coast of Brazil (Amapá, Pará, Alagoas, and Bahia). Now the Amapá coast is its most northern limit.

Genus Cardiomya A. Adams, 1864

Cardiomya cleryana (d'Orbigny, 1842)

(Figs. 1 and 5, Table 2)

Synonymy: Cuspidaria simillima E. A. Smith, 1915 (Rios 2009).

Material examined: CMPHRM 3670A, 1 valve, Oc.V. Almirante Saldanha, Brazil, Off Amapá, 4²7'30"N 50 01'30"W, 20 April 1971; CMPHRM 3678A, 1 right valve and 7 left valves, Oc.V. Almirante Saldanha, Brazil, Off Amapá, 435'30"N 50²1'00"W, 18 May 1971; CMPHRM 3681A, 1 left valve, Oc.V. Almirante Saldanha, Brazil, Off Amapá, $3^{\circ} 37^{\prime} 00^{\prime \prime} \mathrm{N} 50^{\circ} 01^{\prime} 00^{\prime \prime} \mathrm{W}, 08$ May 1971; CMPHRM 3680A, 2 right valves and 2 left valves, Oc.V. Almirante Saldanha, Brazil, Off Amapá, $2^{\circ}$ 53'00"N 48 17'00"W, 14 September 1970; CMPHRM 3671A, 1 valve, Oc.V. Almirante Saldanha, Brazil, Off Pará, $1^{\circ} 55^{\prime} 30^{\prime \prime} \mathrm{N} 47^{\circ} 41^{\prime} 00^{\prime \prime W}, 20$ April 1971; CMPHRM 3679A, 2 right valves and 2 left valves, Oc.V. Almirante

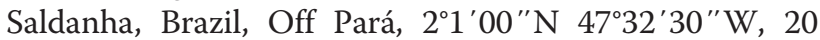
April 1971; CMPHRM 3693A, 3 right valves and 1 left 


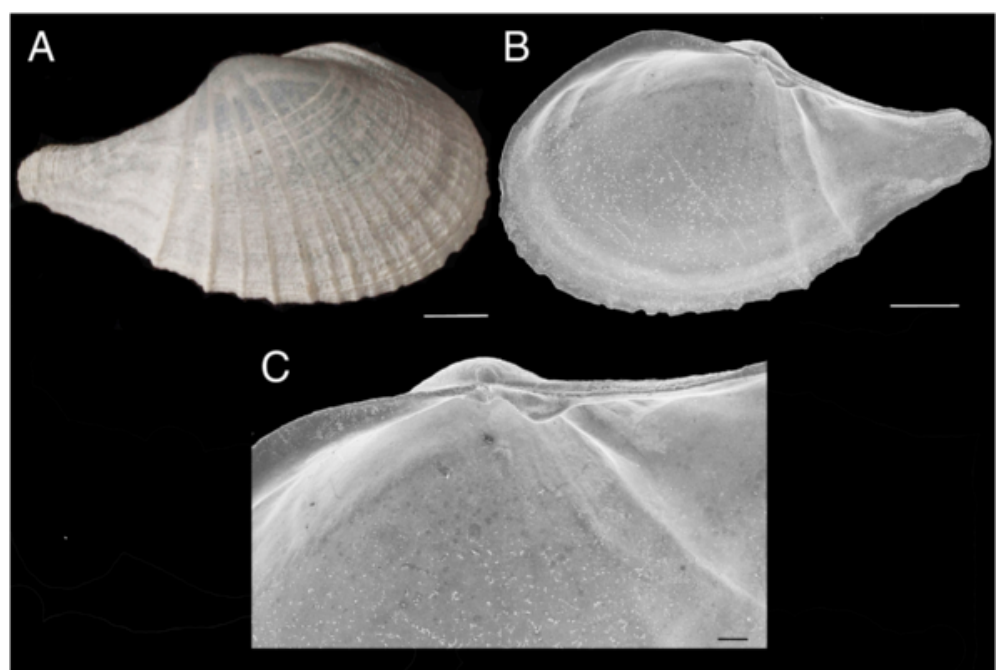

Fig. 5 Cardiomya cleryana (d'Orbigny, 1842) (CMPHRM 3695A). Legends: (a) External view of the right valve; (b) Internal view of the right valve; (c) Hinge of the right valve. Scale bars: $\mathbf{a}-\mathbf{b}, 1 \mathrm{~mm} ; \mathbf{c}, 500 \mu \mathrm{m}$

valve, Brazil, Pernambuco, Itamaracá Island; CMPHRM 3695A, 1 right valve and 1 left valve, Brazil, Pernambuco, Itamaracá Island; CMPHRM 3651A, 1 left valve, Akaroa, Brazil, 9²7'08"S 35 07'07"W, 08 September 1965.

Description: Shell ovate $(11.4 \times 6.9 \mathrm{~mm})$, inequilateral, longer anteriorly, valves inflated, posteriorly rostrate. Rostrum sometimes with fine radial lines. Color white. Umbones opisthogyrate. Sculptured with variable number (15-36) curved radial ribs, that extend beyond the shell edge, yielding a crenulated margin. Ribs concentrated in the anterior region, with distance between them increasing from anterior to posterior. Hinge in the right valve with strong posterior lateral tooth, small fossete. Hinge in the left valve without teeth, with fossete.

Geographic distribution: Atlantic Ocean: Rio de Janeiro, Brazil, to Tierra del Fuego and Falkland Island, Argentina (Rios 2009). In the present study, this species was recorded for off the north-north-east coast Brazil (Amapá, Pará, and Alagoas) and Itamaracá Island, Pernambuco (northeast Brazil).

Table 2 Some morphological and morphometric data of Cardiomya cleryana (d'Orbigny, 1842). Comparative data on the length and height of the valves and size of rostrum of the examined material. Dimensions in $\mathrm{mm}$. The number in italics means the average value of the measurement

\begin{tabular}{|c|c|c|c|c|c|}
\hline Examined material & Length (mm) & Height (mm) & Rostrum (mm) & Ribs $\left(n^{\circ}\right)$ & Val. $\left(n^{\circ}\right)$ \\
\hline 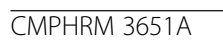 & 8.58 & 5.31 & 2.00 & $>23$ & $L(1)$ \\
\hline CMPHRM 3670A & * & * & * & * & $*(1)$ \\
\hline CMPHRM 3671A & * & * & * & * & $*(1)$ \\
\hline \multirow[t]{2}{*}{ CMPHRM 3678A } & 10.17 & 6.28 & 3.00 & 25 & $R(1)$ \\
\hline & $7.5-8.8-9.6$ & $4.4-5.4-6.0$ & 2.00 & $26-29-36$ & $L(7)$ \\
\hline \multirow[t]{2}{*}{ CMPHRM 3679A } & $8.1-8.3$ & $4.4-5.1$ & 2.00 & 28 & $R(2)$ \\
\hline & $7.6-8.7$ & $4.8-5.6$ & $2^{*}$ & * & $L(2)$ \\
\hline \multirow[t]{2}{*}{ CMPHRM 3680A } & 7.9-11.3 & $6.9-6.4$ & $2.5-3.00$ & 21 & $R(2)$ \\
\hline & $8.7-11.4$ & $5.1-6.9$ & 3.00 & $25-26$ & $L(2)$ \\
\hline CMPHRM 3681A & 8.89 & 5.92 & $1.00^{*}$ & 28 & $L(1)$ \\
\hline \multirow[t]{2}{*}{ CMPHRM 3693A } & $4.5-4.7-5.0$ & $2.4-2.8-3.3$ & $1.0-1.4-1.5^{*}$ & $15-18-21$ & $R(3)$ \\
\hline & 4.72 & 2.91 & $1.4^{*}$ & 17 & $L(1)$ \\
\hline \multirow[t]{2}{*}{ CMPHRM 3695A } & 7.59 & 4.44 & 2.00 & * & $R(1)$ \\
\hline & 9.91 & 6.07 & $1^{*}$ & * & $L(1)$ \\
\hline
\end{tabular}


Bathymetric distribution: 32 to $200 \mathrm{~m}$ (present study); 50 to $225 \mathrm{~m}$ (Rios 2009).

Habitat: Muddy sand (Rios 2009).

Remarks: According to Rios (2009) and Oliveira (2012), four species are recorded in genus Cardiomya A. Adams, 1864 in Brazil: Cardiomya cleryana (d'Orbigny, 1842), Cardiomya ornatissima (d'Orbigny, 1853), Cardiomya perrostrata (Dall, 1881), and Cardiomya striata (Jeffreys, 1876). Cardiomya cleryana is distinguished from other Cardiomya species found in this study mainly by radial ribs with equal sizes and shortly rostrate posteriorly. The anatomy of the arenophilic system of Cardiomya cleryana was described by Oliveira and Sartori (2014). This study extends the northern distribution limit of C. cleryana in the South-western Atlantic with new records for off the north-north-east coast of Brazil (Amapá, Pará, and Alagoas) and Itamaracá Island, Pernambuco (northeast Brazil). Now off the Amapá coast is its northernmost limit.

Cardiomya ornatissima (d'Orbigny, 1853)

(Figs. 1 and 6, Table 3)

Synonymys: Neaera costata Bush, 1885 and Cardiomya glypta Bush, 1898 (in Verrill \& Bush, 1898) (Rios 2009).

Material examined: CMPHRM 3692A, 2 right valves, 5 left valves and 1 shell, Oc.V. Almirante Saldanha, Brazil,

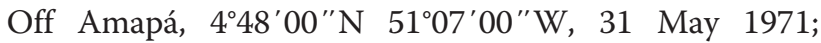
CMPHRM 3675A, fragments, Oc.V. Almirante Saldanha, Brazil, Off Amapá, $4^{\circ} 46^{\prime} 00^{\prime \prime} \mathrm{N} 50^{\circ} 46^{\prime} 30^{\prime \prime} \mathrm{W}$, 06 May 1971; CMPHRM 2021A, 1 left valve, Oc.V. Almirante Saldanha, Brazil, Off Amapá, $4^{\circ} 46^{\prime} 00^{\prime \prime} \mathrm{N} 50^{\circ}$ 46'30"W, 06 May 1971; CMPHRM 3688A, 4 left valves, Oc.V. Almirante Saldanha, Brazil, Off Amapá, 4³5'30" N 50²1'00"W, 18 May 1971; CMPHRM 3690A, 1 left valve, Oc.V. Almirante Saldanha, Brazil, Off Amapá, $4^{\circ}$ $18^{\prime} 48^{\prime \prime} \mathrm{N} \mathrm{50} 17^{\prime} 06^{\prime \prime} \mathrm{W}, 27$ September 1970; CMPHRM 3674A, 1 left valve, Oc.V. Almirante Saldanha, Brazil, Off Amapá, 344'30"N 5007'30"W, 08 May 1971; CMPHRM 3691A, 7 right valves, Oc.V. Almirante Saldanha, Brazil, Off Amapá, $3^{\circ} 10^{\prime} 00^{\prime \prime} \mathrm{N} 50^{\circ} 03^{\prime} 00^{\prime \prime} \mathrm{W}, 05$ May 1971; CMPHRM 3694A, 2 right valves, Oc.V. Almirante Saldanha, Brazil, Off Amapá, 2 ${ }^{\circ} 53^{\prime} 00^{\prime \prime} \mathrm{N} 48^{\circ}$ 17'00"W, 14 September 1970; CMPHRM 3687A, 1 right valve, Oc.V. Almirante Saldanha, Brazil, Off Amapá, $2^{\circ}$ 29'00"N 48³0'00"W, 09 December 1970; CMPHRM 3676A, 1 left valve, Oc.V. Almirante Saldanha, Brazil, Off Amapá, 26'30"N 48²4'00"W, 23 April 1971; CMPHRM 3689A, 5 left valves, Oc.V. Almirante Saldanha, Brazil, Off Pará, $2^{\circ} 02^{\prime} 00^{\prime \prime} \mathrm{N} 48^{\circ} 10^{\prime} 00^{\prime \prime} \mathrm{W}, 21$ June 1971; CMPHRM 3677A, 7 right valves and 3 left valves, Oc.V. Almirante Saldanha, Brazil, Off Pará, $2^{\circ} 1^{\prime} 00^{\prime \prime} \mathrm{N}$ 47 32'30"W, 20 April 1971; CMPHRM 3685A, fragments, Oc.V. Almirante Saldanha, Brazil, Off Pará, $2^{\circ} 27^{\prime}$ 00"N 4745'00"W, 23 April 1971; CMPHRM 3686A, 3 left valves, Oc.V. Almirante Saldanha, Brazil, Off Pará, $1^{\circ}$ 55'30"N 4741'00"W, 20 April 1971; CMPHRM 714A, 5 right valves and 8 left valves, Canopus, Brazil, Off Ceará, 313'S 38³1'W, June 1965 to February 1966; CMPHRM 3648A, 1 right valve, Akaroa, Brazil, Off Alagoas, 9 $2^{\prime} 00^{\prime \prime} \mathrm{S} 35^{\circ} 11^{\prime} 7^{\prime \prime} \mathrm{W}, 10$ September 1965; CMPHRM 3649A, 2 shells, Akaroa, Brazil, Off Alagoas, $9^{\circ} 06^{\prime} 09^{\prime \prime} \mathrm{S} 35^{\circ} 08^{\prime} 07^{\prime \prime} \mathrm{W}, 10$ September 1965; CMPHRM 3650A, 2 left valves, Akaroa, Brazil, Off Alagoas, 9 ${ }^{\circ} 27^{\prime}$ 08"S 3507'07"W, 08 September 1965.

Description: Shell ovate $(13 \times 8 \mathrm{~mm})$, inequilateral, inequivalve, right valve smaller than left one, posteriorly rostrate. Color white, inner surface shiny, outer surface

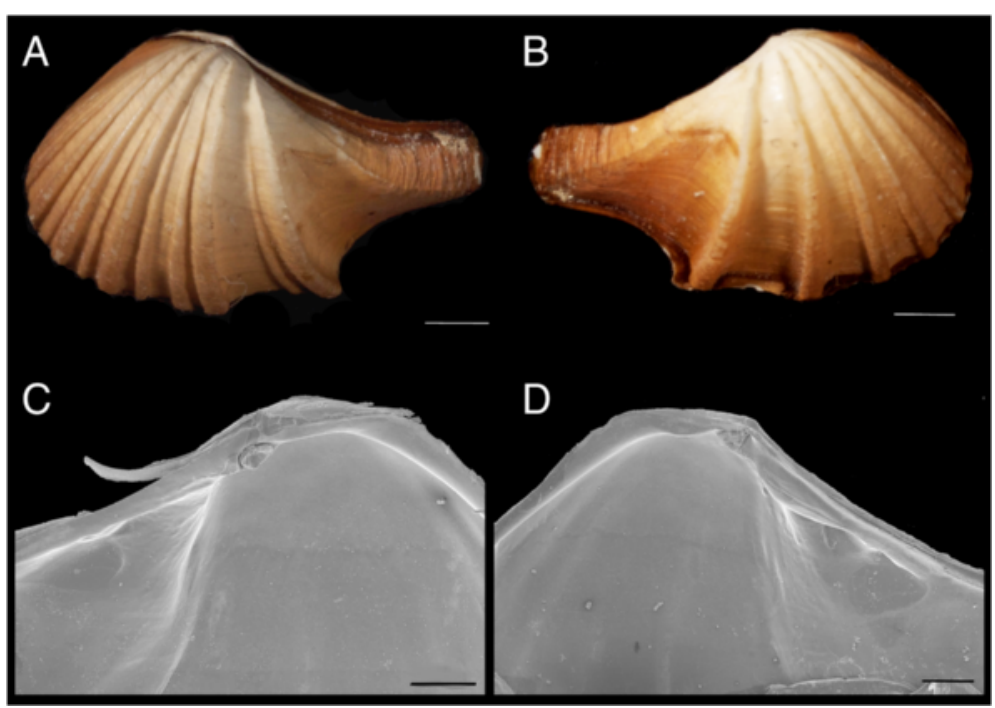

Fig. 6 Cardiomya ornatissima (d'Orbigny, 1853) (CMPHRM 3649A). Legends: (a) External view of the left valve; (b) External view of the right valve; (c) Hinge of the left valve; (d) Hinge of the right valve. Scale bars: $\mathbf{a}-\mathbf{b}, 1 \mathrm{~mm}$; c-d, $500 \mu \mathrm{m}$ 
Table 3 Some morphological and morphometric data of Cardiomya ornatissima (d'Orbigny, 1853). Comparative data on the length and height of the valves, size of rostrum and number of ribs of the examined material. Dimensions in mm. The number in italics means the average value of the measurement

\begin{tabular}{|c|c|c|c|c|c|}
\hline Examined material & Length (mm) & Height (mm) & Rostrum (mm) & $\operatorname{Ribs}\left(n^{\circ}\right)$ & Val. $\left(n^{\circ}\right)$ \\
\hline \multirow[t]{2}{*}{ CMPHRM 714A } & $6.8-7.9-9.4$ & $4.1-4.7-5.4$ & $2.8^{*}-4^{*}$ & $\operatorname{Pr}(6-7)$ & $R(5)$ \\
\hline & $4.8-7.7-9.4$ & $4.4-5.2-5.8$ & $2^{*}-3.2$ & $\operatorname{Pr}(7-9-12), \operatorname{Sr}(3-5-6)$ & $\mathrm{L}(8)$ \\
\hline CMPHRM 2021A & 9.87 & 7 & $2.2^{*}$ & $\operatorname{Pr}(13), \operatorname{Sr}(4)$ & $L(1)$ \\
\hline CMPHRM 3648A & 9.77 & 5.88 & 4.00 & $\operatorname{Pr}(11)$ & $R(1)$ \\
\hline \multirow[t]{4}{*}{ CMPHRM 3649A** } & 6.89 & 4.01 & 3.00 & $\operatorname{Pr}(7)$ & $\mathrm{R}$ \\
\hline & & & & $\operatorname{Pr}(7), \operatorname{Sr}(4)$ & L \\
\hline & 6.66 & 3.94 & 2.4 & $\operatorname{Pr}(7)$ & $\mathrm{R}$ \\
\hline & & & & $\operatorname{Pr}(7), \operatorname{Sr}(3)$ & $\mathrm{L}$ \\
\hline CMPHRM 3650A & $5.8-10.7$ & $3.4-6.8$ & $2-3.4$ & $\operatorname{Pr}(9-10), \operatorname{Sr}(3-4)$ & $L(2)$ \\
\hline CMPHRM 3674A & 7.45 & 5.42 & 2.1 & $\operatorname{Pr}(9), \operatorname{Sr}(3)$ & $L(1)$ \\
\hline CMPHRM 3675A & * & * & * & * & * \\
\hline CMPHRM 3676A & 5.96 & 3.8 & 2.00 & $\operatorname{Pr}(11), \operatorname{Sr}(4)$ & $L(1)$ \\
\hline \multirow[t]{2}{*}{ CMPHRM 3677A } & $5.3-7.0-9.1$ & $3.2-4.1-5.4$ & $2^{*}-2.2-3.4$ & $\operatorname{Pr}(7-8-10)$ & $L(7)$ \\
\hline & $5.6-6.8-8.0$ & $3.3-4.3-4.9$ & $2^{*}$ & $\operatorname{Pr}(13-14), \operatorname{Sr}(3-5)$ & $L(3)$ \\
\hline CMPHRM 3685A & * & * & * & * & * \\
\hline CMPHRM 3687A & 10.76 & 7.01 & 3.2 & $\operatorname{Pr}(7)$ & $R(1)$ \\
\hline CMPHRM 3686A & 7.3-7.9-9.1 & $4.2-4.7-5.7$ & $2.0-2.3-3.0$ & $\operatorname{Pr}(12-14), \operatorname{Sr}(2-3)$ & $L(3)$ \\
\hline CMPHRM 3688A & $6.6-8.8-10.4$ & $4.1-6.0-7.0$ & $2.0-2.6-3.0$ & $\operatorname{Pr}(13-14), \operatorname{Sr}(3)$ & $L(4)$ \\
\hline CMPHRM 3689A & 7.1-7.8-9.1 & $4.2-4.7-5.7$ & $2.0-2.3-3.0$ & $\operatorname{Pr}(12-14), \operatorname{Sr}(2-3)$ & $L(5)$ \\
\hline CMPHRM 3690A & 10.64 & 7.12 & 4.0 & $\operatorname{Pr}(14), \operatorname{Sr}(5)$ & $L(1)$ \\
\hline CMPHRM 3691A & $8.1-9.3-10.6$ & $4.6-5.6-6.9$ & $3.0-3.6-4.1$ & $\operatorname{Pr}(8-10-11)$ & $R(7)$ \\
\hline \multirow[t]{2}{*}{ CMPHRM 3692A } & $6.1-7.7$ & $3.9-4.5$ & $2^{*}$ & $\operatorname{Pr}(9-10), \operatorname{Sr}(2)$ & $R(2)$ \\
\hline & $7.0-7.4-8.0$ & $4.4-4.8-5.5$ & $2.0-2.1-2.5$ & $\operatorname{Pr}(13-14), \operatorname{Sr}(2-4)$ & $R(5)$ \\
\hline \multirow[t]{2}{*}{ CMPHRM 3692A** } & 5.3 & 3.21 & 2.0 & $\operatorname{Pr}(10), \operatorname{Sr}(1)$ & $\mathrm{R}$ \\
\hline & & & & $\operatorname{Pr}(16), \operatorname{Sr}(3)$ & L \\
\hline CMPHRM 3694A & $6.0-13.0$ & $3.7-8.0$ & $2.0-4.5$ & $\operatorname{Pr}(7-10), \operatorname{Sr}(3)$ & $R(2)$ \\
\hline
\end{tabular}

with thin light-brown periostracum. Subequilateral, posterior end longer, umbones slightly opisthogyrate. Right valve convex, with 6-11 prominent radial ribs with interspaces, broader in the posterior region, that extend beyond the edge, making the crenulated margin, ribs well marked on the inner surface of the valve; rostrum truncate, with fine secondary ribs (1-3) and growth lines; hinge with 1 elongate (lamellar) lateral tooth (posterior), anterior region rounded wih projetion next to umbones, deep fossete. Left valve very convex, with 7-16 prominent radial ribs with interspaces, broader in the posterior region, that extend beyond the edge, making the crenulated margin, ribs well marked on the inner surface of the valve; rostrum median truncate, with fine secondary ribs (3-6) and growth lines; hinge without teeth, with deep fossete.
Geographic distribution: Atlantic Ocean: North Carolina to Yucatan, Caribbean and Brazil (Rios 2009; CorreaSandoval and Rodríguez-Castro 2013). In the present study, this species was recorded for off the north-northeast coast of Brazil (Amapá, Pará, Ceará, and Alagoas).

Bathymetric distribution: 20 to $161 \mathrm{~m}$ (present study); 20 to $225 \mathrm{~m}$ (Rios 2009).

Habitat: Sandy and calcareous algae bottoms (Rios 2009).

Remarks: Cardiomya ornatissima is distinguished from other Cardiomya species found in this study mainly by a smaller number of radial ribs that are well-marked on the inner surface of the valve and the presence of secondary ribs in the rostrum.

Cardiomya perrostrata (Dall, 1881)

(Figs. 1 and 7, Table 4) 


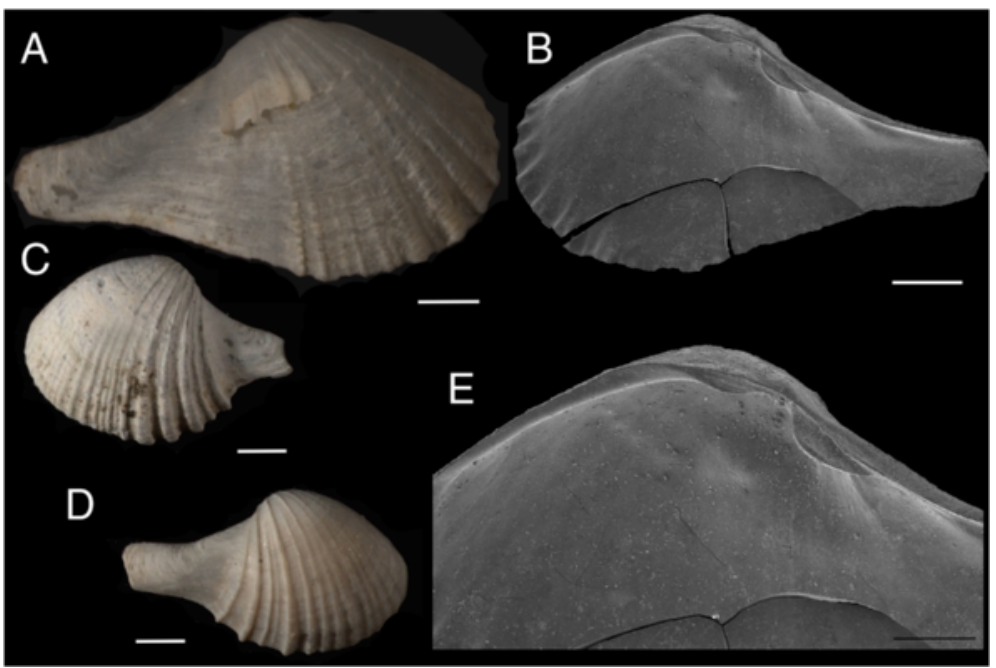

Fig. 7 Cardiomya perrostrata (Dall, 1881). Legends: (a) External view of the right valve; (b) Internal view of the right valve; (c) External view of the left valve; (d) External view of the right valve (CMPHRM 3660A); (e) Hinge of the right valve. a-c; e (CMPHRM 3662A). Scale bars: a-e, 1 mm

Synonymy: see Dall (1886).

Material examined: CMPHRM 3661A, 1 left valve, Oc.V. Almirante Saldanha, Brazil, Off Amapá, 4²7'30" N 5001'30"W, 18 May 1971; CMPHRM 3662A, 1 right valve and 1 left valve, Oc.V. Almirante Saldanha, Off Amapá, $2^{\circ} 53^{\prime} 00^{\prime \prime} \mathrm{N} 48^{\circ} 17^{\prime} 00^{\prime \prime} \mathrm{W}, 14$ September 1970; CMPHRM 712A, 1 right valve, Canopus, Brazil, Off Ceará, $3^{\circ} 13^{\prime} \mathrm{S} 38^{\circ} 31^{\prime} \mathrm{W}$, June 1965 to February 1966; CMPHRM 3657A, 10 right valves and 9 left valves, Brazil, Pernambuco, Itamaracá Island; CMPHRM 3659A, 5 right valves and 2 left valves, Brazil, Pernambuco, Itamaracá Island; CMPHRM 3660A, 1 left valve, Akaroa, Brazil, Off Alagoas, 9 ${ }^{\circ} 1^{\prime} 0^{\prime \prime} \mathrm{S} 34^{\circ} 55^{\prime} 2^{\prime \prime} \mathrm{W}, 10$ September 1965.

Description: Shell small $(14.93 \times 9.45 \mathrm{~mm})$, with a long, narrow rostrum (sometimes with fine lines). Color white, inner surface shiny. Subequilateral, posterior end longer, umbones opisthogyrate. Sculptured with 14 to 32 radial ribs alternating in size, every other one being slightly larger than the other, stronger in the posterior region. Growth lines well marked in some specimens. Crenulated margin. Hinge in the right valve with posterior lateral teeth, with small fossete. Hinge in the left valve without teeth.

Geographic distribution: Atlantic Ocean: North Carolina to Florida, Caribbean, Brazil (Rios 2009; CorreaSandoval and Rodríguez-Castro 2013). In the present study, this species was recorded for off the north-northeast coast of Brazil (Amapá, Ceará, and Alagoas) and Itamaracá Island, Pernambuco (northeast Brazil).

Bathymetric distribution: 35 to 750 m (Rios 2009); 45 to $200 \mathrm{~m}$ (present study).

Habitat: Muddy sand bottoms (Rios 2009).

Remarks: Cardiomya perrostrata is distinguished from

Table 4 Some morphological and morphometric data of Cardiomya perrostrata (Dall, 1881). Comparative data on the length and height of the valves, size of rostrum and number of ribs of the examined material. Dimensions in mm. The number in italics means the average value of the measurement

\begin{tabular}{|c|c|c|c|c|c|}
\hline Examined material & Length $(\mathrm{mm})$ & Height (mm) & Rostrum (mm) & Ribs $\left(n^{\circ}\right)$ & Val. $\left(n^{\circ}\right)$ \\
\hline CMPHRM 712A & 10.66 & 5.79 & $3^{*}$ & 22 & $R(1)$ \\
\hline \multirow[t]{2}{*}{ CMPHRM 3657A } & $3.9-4.7-5.1$ & $2.4-2.9-3.4$ & $1.0-1.3-1.5$ & $16-19-21$ & $R(10)$ \\
\hline & 4.1-4.8-6.1 & $2.7-3.0-3.7$ & $1.0^{*}-1.6-2.0$ & $17-19-22$ & L(9) \\
\hline \multirow[t]{2}{*}{ CMPHRM 3659A } & $3.7-4.4-5.3$ & $2.5-2.6-3.7$ & $1.0^{*}-1.6-2^{*}$ & $14-17-21$ & $R(5)$ \\
\hline & $5.0-5.3$ & $2.8-3.7$ & $1.0^{*}-2.0^{*}$ & $17-21$ & $L(2)$ \\
\hline CMPHRM 3660A & 10.83 & 6.57 & 3.0 & 19 & $L(1)$ \\
\hline CMPHRM 3661A & 14.93 & 9.45 & 3.0 & 32 & $L(1)$ \\
\hline \multirow[t]{2}{*}{ CMPHRM 3662A } & 8.4 & 4.49 & * & * & $R(1)$ \\
\hline & 5.93 & 3.61 & 1.9 & 15 & $L(1)$ \\
\hline
\end{tabular}


other Cardiomya species found in this study mainly by radial ribs with different sizes, a long narrow rostrum, and the presence of two posterior lateral teeth in the right valve, while $C$. cleryana and $C$. ornatissima have just one lateral tooth.

Genus Myonera Dall \& E. A. Smith, 1886

Myonera aff. paucistriata Dall, 1886

(Figs. 1 and 8)

Synonymy: See the checklist made by Janssen and Krylova (2014) for synonymys.

Material examined: CMPHRM 3663A, fragments, Oc.V. Almirante Saldanha, Brazil, Off Amapá, 2०06'30" N 48 24'00"W, 23 April 1971; CMPHRM 3664A, 1 left valve, Oc.V. Almirante Saldanha, Brazil, Off Pará, $1^{\circ} 22^{\prime}$ 00"N 48¹3'00"W, 20 April 1971.

Description: Valve small $(5.01 \times 3.08 \mathrm{~mm})$, ovate, shortly rostrate $(1 \mathrm{~mm}$ in lenght), with 2 strong keels posteriorly (3 ribs well marked and one secondary rib). Outer surface white and shiny. Inequilateral, umbones opisthogyrate. Sculptured with radial and concentric lines that ceases just before the anterior keel. The space between and behind kells is smooth. Left valve without teeth.

Geographic distribution: Indian Ocean: west coast of Malabar (Allen and Morgan 1981); Pacific Ocean (Janssen and Krylova 2014); Atlantic Ocean: North Carolina to Caribbean, Brazil (Campos Basin, Rio de Janeiro) (Rios 2009; Oliveira and Absalão 2009). In the present study, this species was recorded for off the north Brazil (Amapá and Pará).

Bathymetric distribution: 47 to $50 \mathrm{~m}$ (present study); 600 to $760 \mathrm{~m}$ (Rios 2009); 1,050 to $1,930 \mathrm{~m}$ (Oliveira and Absalão 2009); 678 to $3,806 \mathrm{~m}$ (Janssen and Krylova 2014);

Remarks: According to Rios (2009), Oliveira and Absalão (2009), and Oliveira (2012), three species are recorded in genus Myonera Dall \& E. A. Smith, 1886 in Brazil: Myonera paucistriata Dall, 1886, Myonera limatula (Dall, 1881), and Myonera kaiwa Oliveira \& Absalão, 2009. Myonera paucistriata is distinguished from other Myonera species found in Brazil by ovate and shortly rostrate shell with two strong keels posteriorly. Myonera limatula and M. kaiwa have elongate shells with concentric lamellae (Oliveira and Absalão 2009). The examined material in this study is shortly rostrate, with two strong keels posteriorly just like Myonera paucistriata, but is distinguished from the latter mainly by its radial and concentric lines and a well-marked third rib. Unfortunately, it was not possible to identify the specimens at a specific level due to the existence of a single left valve.

Superfamily VERTICORDIOIDEA Stoliczka, 1870

Family VERTICORDIIDAE Stoliczka, 1871

Genus Trigonulina d'Orbigny, 1842

Trigonulina ornata d'Orbigny, 1842

(Figs. 1 and 9, Table 5)

Synonymys: Verticordia caelata Verrill, 1884 (Rios 1994); Verticordia ornata (d'Orbigny, 1853) (Oliveira and Absalão 2010a).

Material examined: CMPHRM 1864A, three right valves and three left valves, Oc.V. Almirante Saldanha, Brazil, Off Amapá, $4^{\circ} 46^{\prime} 00^{\prime \prime} \mathrm{N} 50^{\circ} 46^{\prime} 30^{\prime \prime} \mathrm{W}$, 06 May 1971.

Description: Shell small $(5.6 \times 5.9 \mathrm{~mm})$, equivalve, ovate to rounded, compressed. Color white to cream, inner surface silver-white, outer surface opaque (not shiny). Umbones subcentral, turned to the anterior region; deep lunule. Ligament long. Outer surface with minute granules. 3/ 4 of the anterior surface of the valve sculptured with 10 to 13 curved, deep radial ribs. Posterior region without lines. Anteroventral margin crenulated by the strong ribs. Hinge in the right valve with small cardinal teeth, below umbones. Hinge in the left valve without teeth.

Geographic distribution: Atlantic Ocean: Bermuda, Massachusetts to Florida, Caribbean, Guyane, Surinam, Brazil (Amapá to Rio Grande do Sul) and Sta. Helena Island (Rios 1994; Lamy et al. 2014).

Bathymetric distribution: 20 to $200 \mathrm{~m}$ (Rios 1994; Lamy et al. 2014); $74 \mathrm{~m}$ (present study).

Habitat: Muddy and sand bottoms and clays (Rios 1994; Lamy et al. 2014).

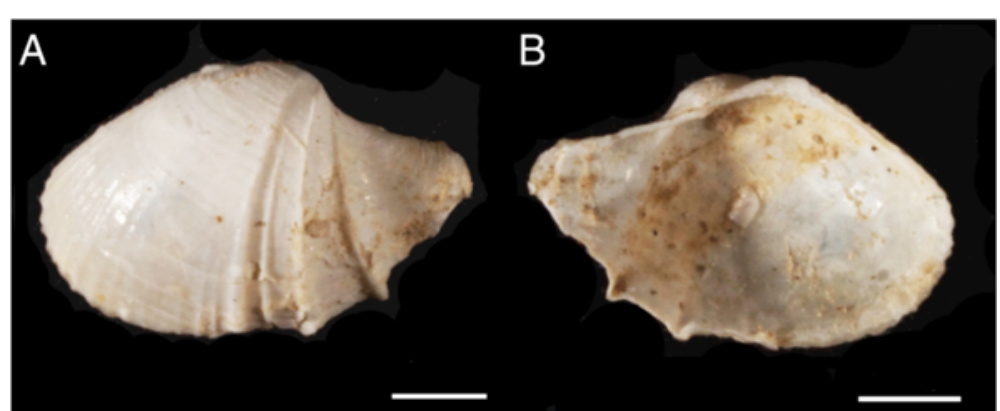

Fig. 8 Myonera aff. paucistriata Dall, 1886 (CMPHRM 3664A). Legends: (a) External view of the left valve; (b) External view of the left valve. Scale bars: $\mathbf{a}-\mathbf{b}, 1 \mathrm{~mm}$ 


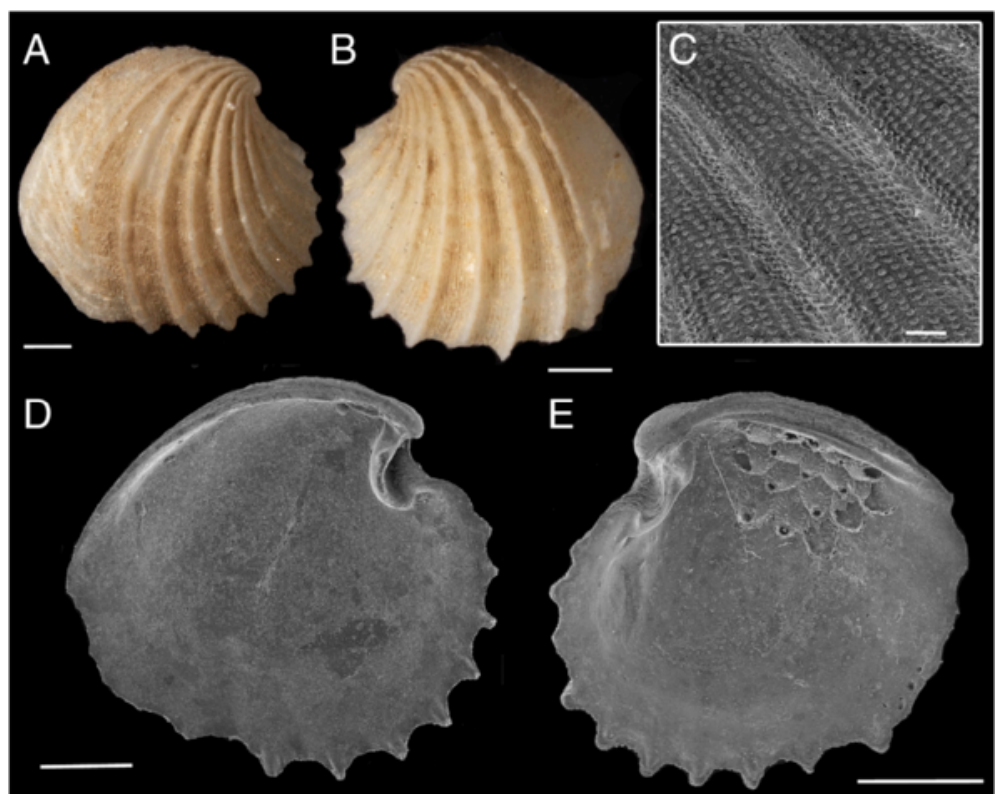

Fig. 9 Trigonulina ornata d'Orbigny, 1842 (CMPHRM 1864A). Legends: (a) External view of the left valve; (b) External view of the right valve; (c) Minute granules of outer surface in detail; (d) Internal view of the right; (e) Internal view of the left valve. Scale bars: a-b, 1 mm; c, $200 \mu$ m; d-e, $1 \mathrm{~mm}$

Remarks: Trigonulina ornata was formerly placed in the genus Verticordia J. de C. Sowerby, 1844, but the new combination was proposed by Poutiers and Bernard (1995), based on the presence of a series of prominent radial ribs and the crenulation of the posteroventral margin. According to Oliveira (2012), Trigonulina ornata is the only species of this genus recorded from Brazil. Trigonulina ornata has a large distribution in the western Atlantic, and it had previously been recorded off the coast of Amapá (north Brazil) (Rios 1994).

\section{Discussion}

Although several studies have been carried out in Brazil with the families Poromyidae, Cuspidariidae, and Verticordiidae in the last few years (e.g. (Oliveira 2012; Oliveira and Absalão 2009, 2010a, 2010b; Absalão and Oliveira 2011; Pimpão et al. 2010; Oliveira and Sartori 2014)) the knowledge about these families is still far from complete, as shown by the new records done in this study. The

Table 5 Some morphological and morphometric data of Trigonulina ornata d'Orbigny, 1842. Comparative data on the length and height of the valves, size of rostrum and number of ribs of the examined material. Dimensions in $\mathrm{mm}$

\begin{tabular}{lllll}
\hline Examined material & Length $(\mathrm{mm})$ & Height $(\mathrm{mm})$ & Ribs $\left(\mathrm{n}^{\circ}\right)$ & Val. $\left(\mathrm{n}^{\circ}\right)$ \\
\hline CMPHRM 1864A & $3.2-4.2-5.6$ & $3.4-4.4-5.9$ & $10-11$ & $\mathrm{R}(3)$ \\
& $3.2-3.9-4.4$ & $3.2-4.0-4.5$ & $10-13$ & $\mathrm{~L}(3)$ \\
\hline
\end{tabular}

Legend: CMPHRM-A malacological collection "Prof. Henry Ramos Matthews" series A, Val. valve; $\left(n^{\circ}\right)$ number of examined valves or ribs, $R$ right, $L$ left present study shows the possibility of two new species of septibranchs to Brazil. However, it was not possible to reach conclusive identifications due to the scarce materials (one valve of each species) and its poor preservation.

Oliveira (2012) points out that one of the main issues regarding Septibranchia is disordered creation of new taxa with the analysis of a few characters, which is not uncommon to exhibit great phenotypic plasticity. Most descriptions of the species discussed here do not distinguish between right and left valves, nor do they provide a more detailed study of morphometry and relevant characters in the differentiation within and between species. By adding new morphological and some morphometric data of the shells, the present study may help in the taxonomy of the septibranchs species. Unfortunately, the amount of morphometric data obtained in this study did not allow their use for distinguishing among analysed species (few shells and many of them poorly preserved). However, we believe that these data are important and may help future morphometric studies.

\section{Conclusion}

This study provide new knowledge about Septibranchia on the Brazilian coast, reducing the gaps in the geographic distribution and extending the distribution limits of some species with new records. New collections probably will discover new records of Poromyidae, Cuspidariidae, and Verticordiidae in the region. 
Table 6 Information about malacological material examined in present study

\begin{tabular}{|c|c|c|}
\hline $\begin{array}{l}\text { Oceanographic } \\
\text { commissions }\end{array}$ & Collector & Locality \\
\hline$\overline{\text { GEOMAR II }}$ & $\begin{array}{l}\text { Oc.V. }{ }^{\text {a }} \text { Almirante } \\
\text { Saldanha }\end{array}$ & North and Northeast Brazil \\
\hline GEOMAR III & $\begin{array}{l}\text { Oc.V. }{ }^{a} \text { Almirante } \\
\text { Saldanha }\end{array}$ & North and Northeast Brazil \\
\hline CANOPUS & Ship Canopus & North and Northeast Brazil \\
\hline AKAROA & Ship Akaroa & North and Northeast Brazil \\
\hline Other dredging & - & $\begin{array}{l}\text { Itamaracá Island - } \\
\text { Pernambuco - Brazil }\end{array}$ \\
\hline
\end{tabular}

${ }^{\bar{a}}$ Oc.V. oceanographic vessel

\section{Methods}

All material studied consisted of shells collected with a dredge during Oceanographic Commission cruises conducted between 1965 and 1971 on the north-northeast Brazilian coast (Table 6). The studied material was deposited in the Malacological Collection "Prof. Henry Ramos Matthews" - Series A (CMPHRM-A) of Universidade Federal do Ceará (UFC), Brazil.

Species identification was performed with the aid of a stereoscopic microscope and specialized taxonomic literature. The examined material consists only of empty shells. All unbroken specimens were measured in total length, height, and size of the rostrum (for members of the Cuspidariidae) with a digital caliper (precision $0.01 \mathrm{~mm}$ ). Species with more than one well-preserved shell were photographed under a scanning electron microscope (SEM) at the Museu Nacional, Rio de Janeiro, Brazil.

The above specimens were used to prepare a dichotomous identification key and redescription of each species.

The lists of examined material contain the register number in the CMPHRM-A, the number of examined valves, the collector, the country, the state, the geographic coordinates, and the collection date.

\section{Abbreviations}

CMPHRM-A: malacological collection "Prof. Henry Ramos Matthews" - series A; Oc.V.: oceanographic vessel.

\section{Competing interests}

The authors declare that they have no competing interests.

\section{Authors' contributions}

CXB, SS AND SGR participated in the acquisition, analysis and interpretation of data. CXB drafted the manuscript. HMC conceived of the study, and participated in its design and coordination and helped to draft the manuscript. All authors read and approved the final manuscript.

\section{Authors' information}

CXB is a biologist and completed her Ph.D. in Marine Sciences at Universidade Federal do Ceará, Brazil. Her research interests are related to the taxonomy, ecology and biogeography of marine mollusks. SS is a biologist and completed her Ph.D. in Zoology at Museu Nacional do Rio de Janeiro, Universidade Federal do Rio de Janeiro, Brazil. Her research interests are related to the taxonomy, ecology and biogeography of marine Porifera. SGR is a biologist complete her M.Sc. in Fishing Engineering at Universidade
Federal do Ceará, Brazil. Her research interests are related to the taxonomy of benthic communities, especially mollusks. HMC is a professor at Universidade Federal do Ceará and completed her Ph.D. in Zoology at University of New Hampshire, United States of America. She is interested in documenting and understanding biodiversity patterns in benthic communities, especially mollusks. Her main research interests are reproduction and predation in gastropods.

\section{Acknowledgements}

The authors thank Paul Valentich-Scott, Natalia Pereira Benain and one anonymous referee for valuable comments on the manuscript. The authors wish to also thank João Eduardo Pereira de Freitas for the photographs used in this study.

\section{Author details}

'Laboratório de Invertebrados Marinhos do Ceará, Departamento de Biologia, Centro de Ciências, Universidade Federal do Ceará, Rua Campus do Pici, s/n, Bloco 909, Pici, CEP: 60440-900 Fortaleza, CE, Brazil. ²Laboratório de Taxonomia de Porifera, Museu Nacional, Departamento de Invertebrados, Universidade Federal do Rio de Janeiro, Quinta da Boa Vista, s/n, CEP: 20940-040 Rio de Janeiro, RJ, Brazil. Programa de Pós-Graduação em Ciências Marinhas Tropicais, LABOMAR, Universidade Federal do Ceará, Av. da Abolição, 3207, Meireles, CEP: 60165-081 Fortaleza, CE, Brazil.

Received: 27 January 2016 Accepted: 8 February 2016

Published online: 08 March 2016

\section{References}

Abbott RT. American seashells - the marine mollusca of the Atlantic and Pacific coast of North America. New York: Van Nostrand; 1974

Absalão RS, Oliveira CDC. The genus Cuspidaria (Pelecypoda: Septibranchia: Cuspidariidae) from the deep sea of Campos Basin, Brazil, with descriptions of two new species. Malacologia. 2011;54:119-38.

Allen JA, Morgan RE. The functional morphology of Atlantic deep water species of the families Cuspidariidae and Poromyidae (Bivalvia): an analysis of the evolution of the septibranch condition. Philos Trans R Soc Lond. 1981;294: 413-546.

Bieler R, Carter JG, Coan EV. Classification of Bivalve families. In: Bouchet P, Rocroi JP, editors. Nomenclator of Bivalve Families, Malacologia, vol. 52. 2010. p. $113-33$.

Bieler R, Mikkelsen PM, Collins TM, Glover EA, González VL, Graf DL, et al. Investigating the Bivalve Tree of Life - an exemplar-based approach combining molecular and novel morphological characters. Invertebr Syst. 2014;28:32-115.

Coan EV, Valentich-Scott P. Bivalve seashells of tropical West America: Marine bivalve mollusks from Baja California to northern Peru. Santa Barbara: Santa Barbara Museum of Natural History; 2012.

Coan EV, Valentich-Scott P, Bernard FR. Bivalve Seashells of Western North America: Marine Bivalve Mollusks From Arctic Alaska to Baja California. Santa Barbara: Santa Barbara Museum of Natural History Monographs 2; 2000.

Correa-Sandoval A, Rodríguez-Castro JH. Zoogeografía de los bivalvos marinos de la costa de Tamaulipas, México. Rev Biol Mar Oceanogr. 2013;48:565-84.

Dall WH. Reports on the results of dredging, under the supervision of Alexander Agassiz, in the Gulf of Mexico and in the Caribbean Sea (1877-78), by the United States Coast Survey Steamer "Blake", Lieutenant-Commander C.D. Sigsbee, U.S.N., and Commander J.R. Bartlett, U.S.N., commanding. XV Preliminary report on the Mollusca. Bull Mus Comp Zool. 1881;9:33-144.

Dall WH. Reports on the results of dredging, under the supervision of Alexander Agassiz, in the Gulf of Mexico (1877-78) and in the Caribbean Sea (1879-80), by the U.S. Coast Survey Steamer 'Blake', Lient--Commander C. D. Sigsbee, U. S.N., and Commander J. R. Bartlett, U.S.N., Commanding. XXIX - Report on the Molluscs Part I, Brachiopoda and Pelecypoda. Bull Mus Comp Zool. 1886;12: $171-318$.

Harper EM, Dreyer H, Steiner G. Reconstructing the Anomalodesmata (Mollusca: Bivalvia): morphology and molecules. Zool J Linnean Soc. 2006;148:395-420.

Janssen R, Krylova EM. Deep-sea fauna of European seas: an annotated species check-list of benthic invertebrates living deeper than $2000 \mathrm{~m}$ in the seas bordering Europe. Bivalvia Invert Zool. 2014;11:43-82.

Krylova EM. New taxa and the system of Recent representatives of the family Poromyidae (Bivalvia, Septibranchia, Poromyoidea). Ruthenica. 1997;7:141-8. 
Lamy D, Martin D, Romano C, Pititto F, Mura MP, Gil J, et al. Complément à l'inventaire des mollusques de Guyane. Xenophora. 2014;148:8-19.

Leal JH. A remarkable new genus of carnivorous, sessile bivalves (Mollusca: Anomalodesmata: Poromyidae) with descriptions of two new species. Zootaxa. 1764;2008:1-18.

Morton B. The Anomalodesmata. Malacologia. 1981;21:35-60.

Oliveira CDC. Considerações sobre a taxonomia de Septibranchia (Mollusca: Pelecypoda) e o estado da arte do conhecimento do grupo no Brasil. Sicardia. 2012;2012:1-12.

Oliveira CDC, Absalão RS. Primeiro registro de Mendicula ferruginosa, Kelliella atlantica e Lyonsiella subquadrata (Mollusca, Pelecypoda) para áquas brasileiras. Biociencias. 2007;15:63-7.

Oliveira CDC, Absalão RS. The genera Myonera, Octoporia, and Protocuspidaria (Pelecypoda, Cuspidariidae) from deep waters of Campos Basin, Rio de Janeiro, Brazil with descriptions of two new species. Am Malacol Bull. 2009; 27:141-56.

Oliveira CDC, Absalão RS. Review of the Septibranchia (Pelecypoda: Mollusca) from deep sea of Campos Basin, Brazil: family Verticordiidae, with description of a new species. J Mar Biol Assoc UK. 2010a;90:809-17.

Oliveira CDC, Absalão RS. Review of the Septibranchia (Mollusca: Pelecypoda) from the deep sea of Campos Basin, Brazil: Family Lyonsiellidae, with description of a new species. Science. 2010b;74:305-16.

Oliveira CDC, Sartori AF. Discovery and anatomy of the arenophilic system of cuspidariid clams (Bivalvia: Anomalodesmata). J Morphol. 2014;275:9-16.

Olsson AA. Mollusks of the tropical eastern Pacific: particularly from the southern half of the Panamic-Pacific faunal province (Panama to Peru), Panamic-Pacific Pelecypoda. Ithaca: Paleontological Research Institution; 1961.

Pimpão DM, Veitenheimer-Mendes IL, Scarabino F. Mollusca, Bivalvia, Cuspidariidae, Plectodon braziliensis (E. A. Smith, 1915) n. comb.: Record of the genus for the South Atlantic, off Brazil. CheckList. 2010;6:648-51.

Poutiers JM, Bernard FR. Carnivorous bivalve mollusks (Anomalodesmata) from the tropical western Pacific Ocean, with a proposed classification and a catalogue of Recent species. In: Bouchet P, editor. Résultats des Campagnes MUSORSTOM. Paris: Mémoirs du Muséum National d'Histoire Naturelle; 1995. p. 107-87.

Rios EC. Seashells of Brazil. Rio Grande: Fundação da Universidade do Rio Grande; 1994.

Rios EC. Compendium of Brazilian Sea Shells. Rio Grande: Editora Evangraf; 2009.

Simone LRL, Cunha CM. Revision of the genus Spinosipella (Bivalvia: Verticordiidae), with descriptions of two new species from Brazil. Nautilus. 2008;122:57-78

\section{Submit your next manuscript to BioMed Central and we will help you at every step:}

- We accept pre-submission inquiries

- Our selector tool helps you to find the most relevant journal

- We provide round the clock customer support

- Convenient online submission

- Thorough peer review

- Inclusion in PubMed and all major indexing services

- Maximum visibility for your research

Submit your manuscript at wuw biomedcentral.com/submit

) Biomed Central 